\title{
Analysis of Effective Ways to Conduct Innovation and Entrepreneurship Education at Colleges and Universities
}

\author{
Zhao Shengbin \\ School of Information \& Control engineering \\ Shenyang Jianzhu University \\ Shenyang, China
}

\author{
Feng Jiyuan \\ School of Information \& Control engineering \\ Shenyang Jianzhu University \\ Shenyang, China
}

\begin{abstract}
With the development of the times and the progress of the society, people's living standards are getting higher and higher, the degree of knowledge is more and more deep, but the spread of education has caused the students to be found everywhere. Facing unprecedented pressure of employment, many colleges and universities have chosen innovation and entrepreneurship education. Hope that through the business to ease the social pressure of employment. But how to make innovation and entrepreneurship education in Colleges and universities has become the focus of higher education. In Colleges and universities, innovation and entrepreneurship education is to cultivate students' entrepreneurship, consciousness, ability and quality. Colleges and universities should actively improve the talent education system, in addition to the combination of education and practice, to cultivate students' entrepreneurial qualities, but also enhance their entrepreneurial skills. Innovation and entrepreneurship education is not only related to school education, but also related to the development of the society, so the university should pay enough attention, through the adoption of various effective ways to carry out innovation and entrepreneurship education.
\end{abstract}

Keywords-Colleges and universities; innovation and entrepreneurship; education; path

\section{INTRODUCTION}

Innovation and entrepreneurship education is a kind of education system engineering. It is also a kind of practical education. It not only has the creativity, but also has the innovation, and has the characteristic of practice and so on. May of this year, the State Council also issued a corresponding innovation and entrepreneurship education document, which not only reflects the country's emphasis on education, more show the country's strong support for innovation and entrepreneurship education and innovation and entrepreneurship education. Today, the rapid development of social economy, the university and students should take the opportunity to actively cultivate the spirit of innovation and entrepreneurship, and then put it into practice. The so-called venture is to show their own personal ideas in reality, entrepreneurs not only need to have the initiative, creativity, but also a spirit of adventure, as well as the ability to deal with various unexpected events and knowledge. While the university is the original driving force for innovation and entrepreneurship, is the root cause of the talent training and the leading force, so colleges and universities should take more responsibility, in-depth exploration, positive reform, and constantly improve and promote innovation and entrepreneurship education system.

\section{CURRENT SitUATION AND PROBLEMS FOR COLlEGE GRADUATES IN ENTREPRENEURSHIP}

\section{A. Lag Behind Concept of Becoming a Talent}

In the Chinese traditional thinking, the idea "hoping one's own sons and daughters to become prominent ones" has long been deeply rooted. Many parents do not hesitate to invite all property only for their children to school, expects his children to one day be able to from universities graduation to work in big cities, to have a stable high work, in their eyes in this way was a success. But with the development of the times, social progress, the reality is often not as imagined, the kind of thinking will only passively let parents again and again disappointed. So in this case should change the kind of talent view, employment not only refers to those seeking employment, entrepreneurship is also a kind of employment, after receiving a good university education, in the quality and knowledge of the business have a great help. In today's market economy, students should learn to choose their own careers, under the premise of knowledge and equipment, students should be more courageous in the face of the road of independent entrepreneurship.

\section{B. Lack of Funds}

Facing the huge pressure of employment, many graduates will also will develop entrepreneurial directions, but ensuing problems will have. The first is capital problem. As a newly graduated students, the vast majority of students do not have much money to start their own business, because of the influence of traditional factors in the majority of the time spent on learning, almost no foreign income, and even the vast majority of students living expenses are given by parents. In the face of this situation, they are not capable of undertaking the funds needed for their pioneering work. 


\section{Lack of Modern Corporate Management Knowledge and Experience}

For graduates who have just stepped into the society, they have only the theoretical knowledge of the University, whether it is the entrepreneurial experience or entrepreneurial skills, can be considered to be zero. In addition to the knowledge, the vast majority of students in the school due to professional limitations, there is no way to improve the system to improve the management of the enterprise theory, so they seriously lack understanding of modern enterprise system and management theory.

Significance of Developing Innovation and Entrepreneurship Education

Developing Innovation and Entrepreneurship Education Can Promote College Graduates to Have Better Jobs

Faced with the higher the pressure, the students accept the school innovation and entrepreneurship education students can start from their own, tap their own potential, to find the opportunity to start, so as to ease the pressure, but also improve their own business opportunities and success rate. In addition to students to seek high quality work, entrepreneurship education to promote employment. According to a large number of data show that the acceptance of innovation and entrepreneurship education of graduates can be well put into work, and very good to complete the task, so that the University's promotion and deepening of innovation and entrepreneurship education can be very good to promote higher quality of college graduates and employment.

\section{Developing Innovation and Entrepreneurship \\ Education Can Promote the Comprehensive Reform of Higher Education}

Comprehensive reform of higher education involves various aspects, such as education resources, teachers, education system, teaching mode, and so on. Because the scope is wide, the depth is deeper, so the road of the comprehensive reform of higher education is difficult. But the development and reform of higher education in our country has already had a decade of time, so it is still continuing, but the university innovation and entrepreneurship is the correct choice of the times background, the solution to the problem of the deep contradictions and problems, and the reform of higher education is the subject of Higher Education. And to promote and deepen the innovation and entrepreneurship education can fully demonstrate the students' personal expertise, and tap their potential, and thus can better promote the modern college students' system and comprehensive reform of higher education.

\section{E. Developing Innovation and Entrepreneurship Education Can Promote the Upgrading of Economic System}

China is a populous country, China wants to develop economic construction, but to deal with the relationship between sustainable and healthy development and GDP growth, to prevent only the development of the economy, the growth of the gross weight, but ignore the economic development quality, do not consider the development of sustainable. Education is a part of social life, although it is subject to economic development, but it has a certain role in promoting the economic development of the society, of course, only when the physical education and education to adapt to economic development, the role will show. Innovation and entrepreneurship education can provide the construction personnel for the modernization construction, thus promotes the social economy development, moreover this also has the benefit to be able to speak of the development, creates the new scientific and technological achievements.

\section{F. Developing Innovation and Entrepreneurship Education Can Promote the Country to Implement Innovation Driven Development Strategies}

A country's development is inseparable from the scientific and technological promotion but no innovation, no science and technology progress, so that innovation is the source of power for the prosperity of the country, but also contribute to the advancement of the society. With the development of science and technology, the global scientific and technological revolution and the industrial revolution, we should seize the opportunity, and steadily deal with the risks and challenges, facing the new trend of economic development and characteristics, in the face of "one hundred two years" of the historical task, deepen the reform of physical mechanism, in addition, should accelerate the implementation of innovation driven development strategy. And the important significance of the university to promote and deepen the innovation and entrepreneurship education lies in the fact that it is conducive to the implementation of innovation driven development strategy.

\section{EFFECTIVE PATHS TO DEVELOP INNOVATION AND ENTREPRENEURSHIP EDUCATION}

\section{A. Cultivate Interest in Entrepreneurship and Improve Entrepreneurship Awareness}

According to the provisions of the education law, the task of higher education is to cultivate advanced specialized talents with innovative spirit and practical ability, to develop science and technology culture, and to promote the construction of socialist modernization. Students are the main force of innovation and entrepreneurship in the contemporary society, and the school is the paradise for students to learn, is the source of resources, is the birthplace of talent. Therefore, the school should bear the responsibility of developing social innovation and entrepreneurship. However, schools to achieve this goal, the school should focus on the students, but also the implementation of the market dynamics, accurate grasp of all kinds of market opportunities. The party's eighteen big report stressed that the ultimate goal of education is to serve the community, so that innovation and entrepreneurship education can better make social development, so that the community to accumulate more wealth, get better service. Of course, in the course of innovation and entrepreneurship education of college students, we should first make the students get rid of the traditional education ideas and have a sense of innovation, and cultivate the spirit of innovation. Of course, to do a good job in education is a freshman, according to students' interest and willingness to provide students with help, and by the professional teachers to teach and skills to explain, 
the most important is to be able to entrepreneurship courses are also included in the course of credit management, to further encourage innovation and interest of students to lay down their hearts of the burden of a bold choice of entrepreneurship.

\section{B. Get Close to Students and Reform Assessment Mechanism}

In order to provide students with the opportunity to provide the students with the guidance of the business should also be reasonable reform of the content and way, for the students, in the assessment process, pay attention to students' ability to analyze and solve problems, to explore the non - standard answer assessment system. Colleges and universities can start from their own reality, to find a suitable starting point, focusing on the popularization of the concept of innovation and entrepreneurship education and related social resources, the school can also be incorporated into the credit system, the establishment of business credit and academic credits of students, school should actively encourage and provide appropriate help, like to turn professional, learning other professional knowledge, etc. When the business and academic conflict, schools should also properly handle it and solve the problem by relaxing the term amendments and creating good environment for students to start their own businesses.

\section{Establish Educational Base and Strengthen Entrepreneurship Practice}

Innovation and entrepreneurship education in Colleges and universities has a strong practical nature, which determines the need for innovation and entrepreneurship education in Colleges and universities to build a practical base, to cultivate the spirit and ability of college students through practical education, to help students accumulate experience in entrepreneurship, and to enhance the entrepreneurial ability of College students. First, the construction of innovation and entrepreneurship education base. With the quality education and the teaching practice, the innovation and entrepreneurship education of innovation and entrepreneurship education and create a full range of business support for college students. At the same time, it is also needed to build the base of the pioneering and innovative education of the college students, establish the special college students' venture fund, and provide financial support for college students' entrepreneurship. In the University, the integration of the "ten enterprises in ten enterprises and ten college students" resources, to create a campus college students' entrepreneurial community and other organizations, to promote college students' independent innovation, self-cultivation, and selfmanagement. In short, innovation and entrepreneurship education in Colleges and universities, colleges and universities can provide venues, training, funding, technology and other aspects of support, to interpret the relevant supporting policies and institutions to enhance the University, business and students to promote innovation and communication, and to promote entrepreneurship to the market, to do a good job of innovation and follow-up tracking service. Second, the construction of innovation and entrepreneurship education base. The innovation and entrepreneurship education base in universities and colleges is extended to the outside of the campus, providing the students with entrepreneurial social practice platform. Colleges and universities to encourage students to take full advantage of leisure time, to make full use of leisure time to ask, to achieve and social, enterprise docking, to participate in social entrepreneurship projects, to strengthen the cultivation of college students' innovation and entrepreneurship.

\section{Develop Cooperation between Schools and Enterprises with the Help of External Forces}

To carry out the cooperation between enterprises and enterprises is not only an inevitable trend of enterprises participating in school innovation and entrepreneurship education, but also an effective way to solve the problems of innovation and entrepreneurship education in Colleges and universities. In innovation and entrepreneurship education in Colleges and universities is more focused on the guidance of the theory, and the practice of the opportunity is often very little, only in the school of innovation and entrepreneurship education is a certain limitation, in order to make up for this defect, so that students not only knowledge but also skills, schools make full use of capital, technology, team management, etc. There will be a certain theoretical knowledge of the students into the real participation in the project decision. This is not only conducive to the expansion of the enterprise project, and for the students to start a business is a rare opportunity to exercise.

Create Entrepreneurship Atmosphere and Expand Campus Culture

The innovation and entrepreneurship education in Colleges and universities should pay attention to create an open, free and relatively relaxed environment to help entrepreneurs to start a business. On the one hand, it can reduce the pressure on the entrepreneurs, on the other hand, we can further strengthen the innovation consciousness of college students, but also benefit the development of innovative culture in Colleges and universities. In the process of creating innovative atmosphere, the need to always focus on the development of academic innovation awareness. Then actively organized a number of campus cultural activities, so that more students are involved in the idea of entrepreneurship, so as to enhance the entrepreneurial culture of infection. In addition, schools should strengthen the leadership of entrepreneurship education for college students, and to increase the students' Entrepreneurship education. You can also through the successful experience to play the experience to stimulate students interest, inspire their courage, and let them know about the business, be prepared. If you have the conditions, you can also invite the successful people to visit the guidance, which will greatly stimulate the enthusiasm of the students to start a business. For college students to develop appropriate support policies, in the economic and financial aspects of college students to help, and actively encourage them to use the venture funds for entrepreneurial technology activities, and actively seek national support for students and social forces to help them embark on the road of entrepreneurship. 


\section{CONCLUSION}

All in all, the innovation and entrepreneurship education in Colleges and universities is a very arduous task, the university should combine their own development, from the reality, actively take all reasonable measures to find all the power and ways to implement innovative education will effectively implement, it is possible to carry out innovation and entrepreneurship education.

\section{REFERENCES}

[1] Zhao Yue. New Measures for Colleges to Promote and Deepen Innovation and Entrepreneurship Education [J]. Economic Research Guide, 2015,20:170-172.

[2] Chen Yujuan. Research into College Students' Innovation and Entrepreneurship Education [D]. Hebei Normal University, 2013.
[3] Gong Min. Theories and Practices of College Students Innovation and Entrepreneurship Education [D]. Huazhong University of Science and Technology, 2005.

[4] Tong Xiaoling. Research into Innovation and Entrepreneurship Education System in Researching Universities [D]. Wuhan University of Technology, 2012.

[5] Zhao Jinhua. Entrepreneurship Education in China's Polytechnical Colleges and Universities Based on Scientific and Technological Innovation [D]. Nanjing Normal University, 2014.

[6] Cao Yang. Research into Innovation and Entrepreneurship Education at Colleges and Universities under the Background of Transferring Economic Development Mode [D]. Northeast Normal University, 2014.

[7] Shi Guoliang. Innovation and Entrepreneurship Education for College Students in the Time [J]. Ideological Education Research, 2010,10:65-68. 